$12-21-2020$

\title{
S-21 as a Liminal Power Regime: Violently Othering Khmer Bodies into Vietnamese Minds
}

Daniel Bultmann

University of Siegen

Follow this and additional works at: https://digitalcommons.usf.edu/gsp

\section{Recommended Citation}

Bultmann, Daniel (2020) "S-21 as a Liminal Power Regime: Violently Othering Khmer Bodies into Vietnamese Minds," Genocide Studies and Prevention: An International Journal: Vol. 14: Iss. 3: 11-26. DOI:

https://doi.org/10.5038/1911-9933.14.3.1768

Available at: https://digitalcommons.usf.edu/gsp/vol14/iss3/5

This Articles is brought to you for free and open access by the Open Access Journals at Digital Commons @ University of South Florida. It has been accepted for inclusion in Genocide Studies and Prevention: An International Journal by an authorized editor of Digital Commons @ University of South Florida. For more information, please contact digitalcommons@usf.edu. 


\section{S-21 as a Liminal Power Regime: Violently Othering Khmer Bodies into Vietnamese Minds}

\section{Acknowledgements}

This paper is the product of a comparative research project at the University of Siegen, Germany, about body knowledge and torture practices under the supervision and leadership of Prof. Dr. Katharina Inhetveen funded by the German Research Foundation. The theoretical framework and research design of this paper is in many ways the result of this collaborative work and discussion, with additional members of the research project working on Guantanamo and Abu Ghraib (Max Breger), as well as Chile and Argentina (Christina Schütz). I am deeply thankful for the support provided by Ben Kiernan, David Simon, and Eve Zucker at the Genocide Studies Program at Yale University, where I was hosted as a visiting fellow for three months to study the archive (including Ben Kiernan's personal collection) and engaged in fruitful discussions about torture and violence under the Khmer Rouge, among other topics. I would also like to thank Youk Chhang and Ros Sampeou at DC-Cam, the team at the Legal Documentation Center of the ECCC, Kosal Path from Brooklyn College, Barbara Thimm at the Tuol Sleng Genocide Museum and Archive, and Kim Hour Seng and Ratanak Khun for assisting me with documents and in the field. Finally, two reviewers-and one in particular-at the very last moment prevented an embarrassing loss of face on my part. 


\title{
S-21 as a Liminal Power Regime: Violently Othering Khmer Bodies into Vietnamese Minds
}

\author{
Daniel Bultmann \\ Universität Siegen; Humboldt-Universität zu Berlin \\ Siegen, North-Rhine Westphalia; Berlin, Germany
}

\section{Introduction}

The central prison of the Khmer Rouge-with its detention center on the compound of the former high school, Tuol Svay Prey, in the Cambodian capital, Phnom Penh-was tasked with uncovering traitorous networks in the populace and especially within its own revolutionary movement. ${ }^{1}$ Together with several buildings in the surrounding area, Tuol Svay Preycommonly referred to as Tuol Sleng, the name of a neighboring primary school-became a torture and execution center codenamed S-21, in which inmates were forced to confess to working for foreign powers as agents of the CIA, the KGB, or the Vietnamese. ${ }^{2}$ In the end, however, as laid out in a party document titled The Last Joint Plan and created from information from confessions at S-21, the Soviets were considered to be the secret head behind all traitorous activities, while the US "colluded" and the Vietnamese acted as "implementors." 3 Every Cambodian resisting the regime was considered a traitor fallen to the territory-swallowing Vietnamese, who were attempting to finalize their centuries-old expansionist plan to annex "Kampuchea," using the Americans and Soviets as their vehicle. As said in a common slogan, the bodies of the traitors was considered Khmer, but their minds were deluded by Vietnamese thoughts: "Khmer bodies, Vietnamese heads." 4 While almost all sections of the populace, according to the analysis of the party, 5 suffered to varying degrees from an infection of individualist and capitalist thoughts, those in S-21 were regularly labeled enemies, who "became one hundred percent Vietnamese" in their thinking. ${ }^{6}$

While the Khmer Rouge used the derogatory Khmer term Yuon for "Vietnamese," its use did not necessarily imply that their enemies were working strictly and directly at Hanoi's behest. Often, it served primarily to denote a duplicitous, devious, and anti-Khmer mind. ${ }^{7}$ Hence, in terms of semantics, while a "Khmer body with a Yuon head" possessed a twisted "Vietnamese" mind, the enemy might nevertheless be forced to confess that he or she was serving the CIA or KGB. Being Yuon covered "Vietnameseness" and had xenophobic overtones suggesting a dangerous, invisible, duplicitous, and anti-Khmer otherness. Even though many Cambodians would claim that Yuon is just an outdated word for Vietnamese (especially if they sympathize with the current opposition), this article prefers to use the term Yuon or to refer to "Vietnameseness" coupled with otherness rather than simply translating Yuon as Vietnamese.

Thought reform (which others were subjected to by means of productive labor, selfcriticism, and indoctrination) would not work on such individuals; they were beyond reform. The problem-and also the thesis of this paper-was that the regime could not solely rely on visual, social, or ethnic characteristics to find and punish enemies of the revolution but also had

\footnotetext{
${ }^{1}$ David Chandler, Voices from S-21: Terror and History in Pol Pot's Secret Prison (Berkeley: University of California Press, 2000).

2 The fact that Tuol Sleng was actually a school nearby and not the schooling compound that is now the site of the Tuol Sleng Museum tells a great deal about the lack of knowledge we had for a long time about the size and structure of the actual security compound; Anne-Laure Porée, "Tuol Sleng, L'Histoire Inachevée d'un Musée Mémoire," Moussons 30, no. 2 (2017).

3 Archived Document, "The Last Joint Plan," No. D17488, Sterling Library, Yale University and the Documentation Center of Cambodia, Phnom Penh.

${ }^{4}$ Henri Locard, Pol Pot's Little Red Book: The Sayings of Angkar (Chiang Mai: Silkworm Books, 2004), 179.

5 Sophal Ly, "Social Classes in Democratic Kampuchea," Searching for the Truth 34 (2002), 14-17.

${ }^{6}$ David Hawk, "Tuol Sleng Extermination Centre," Index on Censorship 1 (January 1986), 31.

${ }^{7}$ I am grateful for an anonymous reviewer's comment on this.
}

Daniel Bultmann. "S-21 as a Liminal Power Regime: Violently Othering Khmer Bodies into Vietnamese Minds." Genocide Studies and Prevention 14, no. 3, 11-26. https://doi.org/10.5038/1911-9933.14.3.1768.

(c) 2020 Genocide Studies and Prevention. 
to make treason and, along with this, the Yuon mind visible through violent practice: they had to "uncover" it through liminal ritualization and violent othering. What one can see in S-21instead of a pre-established compartmentalization ${ }^{8}$-is a constant and ritualized process of violent and liminal othering. This ritualization of violence explains the structure, the scripts and procedural logics behind the violent practices in S-21. The whole institution of S-21 and its violent practices and operations served to reveal a "Vietnameseness" and/or otherness within the victims and to prove not only their guilt with regard to a singular crime but also a long history of treason and collaboration with the enemy, as well as a moral shortcoming that put them outside their own imagined Khmer moral universe and part of a larger scheme. The victims were made to inscribe their non-Khmer nature and Yuon minds on their bodies and into their confessed biographies. The initial and, for the ideology of the revolution, problematic sameness of the victims needed to be reshaped into a profound otherness in terms of thinking, lifestyle, and biography. Violent practices such as torture, mistreatment of inmates, and execution needed to signify or-in a more literal sense-transform the inmates into what the regime believed they had become: essentially Yuon in mind, weak in morality, and traitorous in practice. This enforced and violent transition into a true "other" was accompanied by a semiotic process inscribing Vietnamese- and otherness into the victim through a liminal power regime that served to signify as well as enable a transition to this new status.

Alexander Laban Hinton-inspired by Arjan Appadurai's theory of ethnic violencehas thoroughly and accurately described the torture at S-21 as a liminal process or lethal rite of passage, "an institutional attempt to organize and crystallize difference on politically uncertain bodies." 9 He shows how politically uncertain bodies in S-21 were treated as polluted and stripped of their markers of humanity and basic freedoms to "manufacture" an absolute, ethnically codified difference that was inscribed in every enforced expression of the inmates. ${ }^{10}$ This article, while largely in line with Hinton's analysis, considers additional aspects of liminality, including its symbolism with regard to Buddhist morality (individualistic greed, lust, and striving for power), Buddhist hell (dogs and torture practices), and anti-Vietnamese semiotics as well as discussing the importance of the last stage of the rite at S-21, with mass graves representing permanent liminality or a halted aggregation phase that keeps victims trapped as suffering ghosts (called khmouch).

In so doing, the paper also adds to a literature analyzing extreme forms of violence such as torture or cruelties in concentration camps as liminal practice. ${ }^{11}$ Liminality, as described by the anthropologists Victor Turner and Arnold van Gennep, is a stage within initiation rites serving as a passage from one status to another.12 The key point within this stage, which comes after a stage of separation from the social body, is that the initiate endures a period of being outside the social order during which new forms of identity are inscribed into his or her mind and often quite literally into his or her body. The article thus uses the concept of liminality in order to highlight that the violent passage endured by the victims in S-21 is not just an act of othering, making them Yuon, but it follows a certain ritual script; it has a structure, it uses certain cultural scripts of transition (in this case, for instance, from notions of Buddhist hell), and it is also characterized by typical markers of liminality. Liminal beings are in a stage betwixt and in between; they are considered polluted, dangerous, naked (literally and symbolically),

\footnotetext{
8 Abram De Swaan, The Killing Compartments: The Mentality of Mass Murder (New Haven: Yale University Press, 2015).

9 Alexander Laban Hinton, Why Did They Kill? Cambodia in the Shadow of Genocide (Berkeley: University of California Press, 2005), 226; also see Arjun Appadurai, "Dead Certainty: Ethnic Violence in the Era of Globalization," Public Culture 10 (1998), 225-247.

10 Ibid.

${ }^{11}$ Jörg Zirfas, "Rituale der Grausamkeit, Performative Praktiken der Folter," in Die Kultur des Rituals: Inszenierungen, Praktiken, Symbole, ed. Christoph Wulf and Jörg Zirfas (München: Fink, 2004); Ulrich Oberdiek, "Initiation, SelbstFolter und Folter: Begriffe und Ansätze in der Ethnologie," in Das Qü̈len des Körpers: Eine historische Anthropologie der Folter, ed. Peter Burschel, Götz Distelrath, and Sven Lembke (Köln: Böhlau Verlag, 2000).

12 Victor Turner, The Ritual Process: Structure and Anti-Structure (London: Routledge, [1969] 2017); Arnold van Gennep, The Rites of Passage (Chicago: University of Chicago Press, 1960).
} 
and wild. They are in a space outside of the social realm, in the wildness, and they transition. In the case of the inmates of S-21, they seem to transition into the status of being Yuon, which at the same time is the status of being outside of the moral order, of moral otherness.

The violent rite of passage thus-in stark contrast to classic rites of passage such as entering adulthood, getting married, or death rituals-serves to uncover a "Vietnameseness" and otherness, while potentially also forcing the victims into a permanent moral liminality-a point that will be discussed in view of the execution practices of the Khmer Rouge at the very end of this paper. The victims of S-21 die a death which keeps them in an ambivalent stage of either becoming Vietnamese and/or of being permanently caught in liminality. The ritual process serves to separate the victims from being "Khmer;" it visualizes an invisible status as an enemy standing outside the moral and collective order. The article thus proceeds by first explaining the problematic invisibility of the enemies of the revolution. Then follows a section on violent practice in S-21 as a rite of passage of separation, ambiguity, and liminality. Afterward, two sections explain the process of uncovering and inscribing the "Vietnameseness" of the victims through torture and confessions. The article closes with a discussion of the aggregation phase, which normally signifies the moment where initiates enter their new status, but which in this case remains ambiguous and points toward a permanent liminality.

\section{Invisible Enemies of the Revolution}

The invisibility of the enemy posed a threat to the revolution, and the leadership of the regime constantly engaged in attempts to explain to its underlings how to recognize an enemy. While socioeconomic background was vital in judging the counterrevolutionary potential of people, such as whether they came from upper and higher-educated classes or as "new people" from the cities, almost everyone was considered able to become a loyal follower of the regime-and absolutely everyone was at risk of turning Yuon in mind. Farmers, on the other hand, were considered purer people and the base of the revolution and therefore had more rights, easier access to goods, and protections (including from imprisonment). Most decisive, however, was whether someone resisted the new order. Political resistance made them fundamentally (and ethnically) different. Thus, traitorous thinking was to be derived from traitorous behavior, although this might not be as clear-cut as it seems. While it was made clear that letting an enemy walk free might result in being considered an enemy themselves, cadres had to deal with vague descriptions of their enemies, sometimes tipping into outright comedy, as in this example by Khieu Samphan.

We see the enemy acting already, but we say 'Not a problem.' This comes from our instructions on not yet being hot. As when the enemy drinks palm sugar water, and then defecates in the drinking tube, we say that he is lazy, not that he is an enemy. In fact, he is an enemy. ${ }^{13}$

The expression "not yet being hot" already introduces an important ideological theme of the Khmer Rouge: those purified into clean revolutionary thought should be clear-sighted enough to recognize enemies simply by observing abnormalities in their behavior. These classic Buddhist themes of purity and enlightenment, in turn, also meant that those who failed to "see" an enemy were not pure and hence might be considered as polluted if not enemies themselves. Seeing enemies where others might not see them developed into proof of revolutionary purity, while not seeing them created a high risk of suspicion.

That is why the notebooks of interrogators at S-21 are full of study sessions on how to recognize enemies. One interrogator, Chan, noted down that " $9 \%$ [of the population] are weak[,]

\footnotetext{
${ }^{13}$ Meng-Try Ea, The Chain of Terror: The Khmer Rouge Southwest Zone Security System (Phnom Penh: Documentation Center of Cambodia, 2005), 7.
} 
$1 \%$ very weak[,] $1 \%$ are enemies." 14 But how can you know whether someone is a member of the CIA, KGB, or Vietnamese enemy networks? Another interrogator wrote:

There are two types of enemies the Party arrest:

a) People who conduct anti-party activities of all kinds at the local level and those who freely make contact with others beyond the Party's order.

b) People who appear in connection with [the enemies] in Santebal reports and have been clearly examined and investigated. ${ }^{15}$

The most problematic enemy was the internal enemy: cadres hiding in the party with the goal of destroying it. These were difficult to find. All that could be done was to look out for indicators of sabotage, such as being lazy, being late for work, and slowing down work in any way. ${ }^{16}$ Yet, while some in the populace and within the movement were considered merely a bit confused, others to be simply sticking to old habits of being and acting with a "free spirit"17 (serei-niyum), and still others as having "accidentally" become enemies, those imprisoned at S-21 fell under the category of enemies to be "smashed." 18 Though the inmates of the security apparatus, known as Santebal, may not have looked like enemies, they clearly were, and there was to be no doubt about it: "As for our security department, the enemies are handcuffed; although they do not have guns and apparently look as if they were revolutionaries, in actuality they are enemies." 19 Study sessions explaining the party policy towards enemies were not very helpful, either. Notes from these sessions cycle around repetition of vague instructions to look "closely" at the biography of the inmates, to be vigilant with regard to one's environment (even one's own colleagues), and to never, ever let a single enemy walk free. The vagueness of the enemy and the fact that anyone could be one created a constant threat that resurfaced upon encounters with the sameness of the other. For one, the party had to insist that cadres should not become "weak," feel pity, and identify with the enemy. Furthermore, the otherness of the cadres" own self might turn them into enemies any time. They constantly saw colleagues being imprisoned and killed for their impurities and "mistakes" and feared being next. ${ }^{20}$

\section{Separation, ambiguity, and liminality}

The process of interning, torturing, and turning subjects into enemies in S-21 (and beyond) resembled a transformative ritual, a rite of passage into a new symbolic status: that of being one hundred percent Yuon in mind. Victor Turner revitalized Arnold van Gennep's concept of liminal rituals to describe a three-staged status transition:

Van Gennep has shown that all rites of transition are marked by three phases: separation, margin (or limen), and aggregation. The first phase of separation comprises symbolic

\footnotetext{
14 Archived Document, “The Chan Notebook," Document No. E3/833, Extraordinary Chambers in the Courts of Cambodia (ECCC), accessed June 2019 at https://www.eccc.gov.kh/sites/default/files/documents/courtdoc/ 00184579-00184618 E3 833 EN.TXT.pdf.

15 Archived Document, "Statistics Santebal S-21 (Interrogator's Notebook)," Document No. D06938, Sterling Library, Yale University and the Documentation Center of Cambodia, Phnom Penh.

16 Archived Document, "Notebook of a Cadre," Document No. D15375, Sterling Library, Yale University and the Documentation Center of Cambodia, Phnom Penh.

17 Archived Document, "Untitled," Document No. D21228, Sterling Library, Yale University and the Documentation Center of Cambodia; Kosal Path and Angeliki Kanavou, "Converts, not Ideologues?: The Khmer Rouge Practice of Thought Reform in Cambodia, 1975-1978," Journal of Political Ideologies 20, no. 3 (2015), 314.

18 Ibid.

${ }^{19}$ Document No. D06938, emphasis added.

${ }^{20}$ Interview with former S-21 interrogator by the author, Kandal province, Cambodia, March 30, 2019.
} 
behavior signifying the detachment of the individual or group either from an earlier fixed point in the social structure or a set of cultural conditions (a 'state'); during the intervening liminal period, the state of the ritual subject (the 'passenger') is ambiguous; he passes through a realm that has few or none of the attributes of the past or coming state; in the third phase the passage is consummated. ${ }^{21}$

The liminal being is in a state in which it reflects on society, its morals, and its own role in it in order to transition into its new status. While in transition, it is associated with wildness and ambiguity, as it also draws power from being in touch with worlds beyond. It is betwixt, nowhere, ambiguous, dangerous, wild, and in-between.

As in all but in other cases usually non-violent and voluntary liminal rituals, transition for the inmates of S-21 started with separation from the cooperative: a blindfolded transfer signifying the entering of a realm outside of and invisible to the "normal" order, in a secluded and secret space. ${ }^{22}$ In that new space, they were photographed and registered with number plates and fingerprints, a system stemming from French colonial prisons. ${ }^{23}$ Then they entered a realm where they were initially treated-in an interaction between physical and social body statuses-as socially unclear and hence unclean bodies without clear identity. ${ }^{24}$ They were stripped of their clothes (only keeping their underwear) and left shackled, lying close together with dozens of other inmates or in a tiny cell in their own dirt, washed only irregularly in "bathing sessions" with a water hose. 25 Dirt became part of their personal space. Correspondingly, they were forced to relieve themselves into an ammunition box. Instead of separating the liminal dirt into the realm of the wild as a sign of ordered spheres and identities, they were forced to eat, sleep, and defecate in the same spot. ${ }^{26}$

Their treatment as inmates resulted in a complete and violent loss of identity and its articulations. Inmates not only were registered with numbers and addressed by numbers by their guards but also were unable to move and kept in shackles at all times. They needed to request permission for any type of bodily movement (sitting upright instead of lying on the floor, for instance). They were deprived of control of their time. They were even, at times, prevented from sleep. ${ }^{27}$ They were not allowed to talk to others (just centimeters away). They lived without personal belongings and were unable to perform rituals of any sort. At the same time, they were treated as only numbers, who shared their space with anonymous and, at times, sick, dying, or even dead co-inmates. Correspondingly, the detention rooms were also devoid of character: empty rooms containing only signs of power (shackles, defecation boxes, and boards on which the cadres wrote behavioral rules inmates were supposed to adhere to). ${ }^{28}$

${ }^{21}$ Victor Turner, The Forest of Symbols: Aspects of Ndembu Ritual (Ithaca: Cornell University Press, 1967), 94; see also van Gennep, The Rites of Passage.

22 It should be added that this was not an exception but rather the rule under the Khmer Rouge. Usually, larger security centers and reeducation camps had been constructed in secluded areas far off from villages such as former pagodas or school buildings. One reason for this was the need for secrecy. But it also followed rather simple demands of practicality as these concrete buildings and their spatiality usually suited the purpose of detaining, torturing and executing the inmates best. Compare for example the description of localities in the Southwest Zone in Ea, Chain of Terror.

23 Michelle Caswell, Archiving the Unspeakable: Silence, Memory, and the Photographic Record in Cambodia (Madison: University of Wisconsin Press, 2014), 32-47.

24 Mary Douglas, Purity and Danger: An Analysis of Concepts of Pollution and Taboo (New York: Routledge, [1966] 2002).

${ }^{25}$ Hinton, Why Did They Kill?, 225.

${ }^{26}$ Ibid.

${ }^{27}$ Archived Document, “Excerpts from the S-21 Interrogator's Manual," Document No. D17138, Sterling Library, Yale University and the Documentation Center of Cambodia, Phnom Penh.

28 Vann Nath, A Cambodian Prison Portrait: One Year in the Khmer Rouge's S-21 (Bangkok: White Lotus Press, 1998), $36-47$. 
At the same time, the liminal beings were like in rituals described by Turner within tribal societies considered polluted, ambiguous, and dangerous. ${ }^{29}$ Interaction between inmates was suppressed, possibly also in order to prevent contagious spreading of ideas and counterrevolutionary activities among them. ${ }^{30}$ Likewise, interrogators and guards were told not to touch them, such as by beating them with bare hands or feet, but to use wire or wood instead, and strictly advised not to interact with them, not to talk to them about their background and life prior internment. Using bare hands on women particularly was thought to risk pulling cadres into moral offenses and sexual lust, drawing them away from "doing politics." 31 Interrogators were constantly told to keep their "mastery" (mchas) when interacting with the enemy and to beware of their "reactions" (brati kam), which might endanger them and the revolution: by being attacked as a result of not paying proper attention; by being drawn into emotional reactions, such as feeling pity for them; by becoming hesitant, doubtful, or sexually aroused; by getting angry, losing control, and starting to use violence without political purpose; and, more directly, by losing vital information or allowing individualistic weaknesses such as laziness and self-interest to enter revolutionary practice. ${ }^{32}$ The line between friend and enemy of the revolution was thin, and the sameness in the other a constant emotional threat that needed to be controlled and suppressed by commitment, mastery, or-in Khmer Rouge vocabularyabsoluteness (doch kat). The logic was clear: everyone had residues of individualistic thinking; purification was a constant struggle, not just for enemies of the people but for everyone-and being confronted with the worst kind of non-revolutionary thinking and behavior demanded security practices and strict emotional mastery. Without these, there awaited a slippery slope that leads all too easily to treason.

The liminality of the S-21 is also part of its semantics, as, for example, when inmates were called "a-preet" by the cadres. ${ }^{33}$ In Cambodian Buddhism, preet are ghosts caught in hell, tormented for the evil deeds they committed in life. They must endure torture for millions of years before they can be transformed into new beings. This liminality also appeared in the naming of the three interrogation units and styles: cold, chewing, and finally hot (mainly depending on the degree of torture involved). This also reflected Buddhist notions of transformation and purification as processes of "heating oneself." 34 Finally, beyond infrastructural convenience, there was a symbolic element indicating liminal transition in choosing pagodas and schools across the country as places of purification and mental transformation. In addition to being concrete structures that served well for the construction of prisons, these buildings were deliberately chosen for what were seen as, quite literally, "reeducation" centers. Evidence for this notion lies in the facts that colonial and prerevolutionary prisons were not used for this purpose and that former school buildings were chosen even in Phnom Penh. 35

\section{Uncovering I: Torture}

Torture served to uncover the traitorous mind. In this regard, it differed from the liminal realm of detention, which was devoid of semiotics inscribing identities to the inmates, as one can find many references to the act of making the Vietnamese mind and otherness of the victims visible during torture. This becomes especially clear when reading the explanations of an interrogator about the usage of a technique called paying homage, which indicates the centrality of

\footnotetext{
${ }^{29}$ Turner, The Forest of Symbols, 93-111.

30 Archived Document, "Regulation Concerning Locks, Shackles and Measures," Document No. D16971, Sterling Library, Yale University and the Documentation Center of Cambodia, Phnom Penh.

${ }^{31}$ Document No. D15375.

32 Document No. E3/ 833; Document No. 15375.

${ }^{33}$ Chandler, Voices from S-21, 118.

${ }^{34}$ Ian Harris, Buddhism in a Dark Age: Cambodian Monks under Pol Pot (Honolulu: University of Hawaii Press, 2013), 54.

${ }^{35}$ Quite fittingly, S-21 moved to this location from a former Lon Nol prison that was in use until 1976.
} 
uncovering and, simultaneously, transformation (of consciousness) through torture as a violent means of othering:

Paying homage to images of dogs is introduced because it has political meaning - one dog is imperialism, and another dog is the territory-swallowing Yuon enemy. We forced them to pay homage of images of dogs in order to test them because when they were arrested, $90 \%$ pretended that they were revolutionists. Once they pay homage to images of the two dogs, it means that they accept they are traitors. Concerning consciousness: we change their consciousness. Concerning assignment: Do they respect Santebal or not? ${ }^{36}$

Since interrogators noted that they forced inmates to do it several times or for as long as half an hour, "paying homage" probably meant that the interrogated had to remain in a bodily position called "airplane," a famous torture technique widely applied during the Chinese Cultural Revolution. Inmates in this position would resemble followers bowing to the dog image, signifying that they had animal-like masters and belonged to a lineage of a different species. ${ }^{37}$ Semiotically reinforcing their misled inner servitude to the Vietnamese, these images of dogs often had Ho Chi Minh's head on it. To further signify that they had deluded minds twisted against the revolution, they were also forced to "pay homage" to chairs, tables, and walls. Similarly simulating an interplay between master and servant, a guard rode piggyback on the inmate on the way upstairs to the cell. ${ }^{38}$

Some of the torture techniques were also considered "Vietnamese," as highlighted by Duch during the Khmer Rouge Tribunal: "the [...] method was about the suffocation technique that the 'Yuon' used to torture prisoners in order to obtain their confessions-that is, putting a plastic bag over a prisoner's head until the prisoner was unconscious." 39 Besides othering and inflicting pain through techniques such as electrocution, pulling of nails, drowning, cigarette burns, beatings, and pouring salt and soap into open wounds to enable an inmate's transformation into a confessor, torture semiotics also involved wildness and liminality. Interrogators, for instance, had poisonous centipedes and scorpions crawl over their victims or pulled off their shirts and put them "with the mosquitos." 40 Two techniques signifying their belonging to a liminal space and moral otherness seem disputed: hanging them from a crossbar, previously used by students for sports, as well as drowning them upside-down into a water tank on the patio of the building. While interrogators denied the usage of both techniques, claiming for instance that the water tanks were only used to store fertilizer (also in interviews with the author), former prisoner Vann Nath captured these techniques in a painting, depicting a scene that he claimed to have seen from a window while painting portraits of Pol Pot (see Image 1).

\footnotetext{
36 Document No. E3/ 833.

37 Chandler, Voices from S-21, 132-133.

38 Vannak Huy, Bou Meng: A Survivor from the Khmer Rouge Prison S-21, Justice for the Future Not Just for the Victims (Phnom Penh: Documentation Center of Cambodia, 2010).

39 Archived Document, "Transcript of Trial Proceedings," June 16, 2016, Document No. E1/439.1, Extraordinary Chambers in the Courts of Cambodia (ECCC), accessed June 2019 at https://www.eccc.gov.kh/sites/default/ files/documents/courtdoc/2016-10-18\%2011\%3A52/E1 439.1 TR002 20160616 Final EN Pub.pdf.

${ }^{40}$ Document No. D17138.
} 


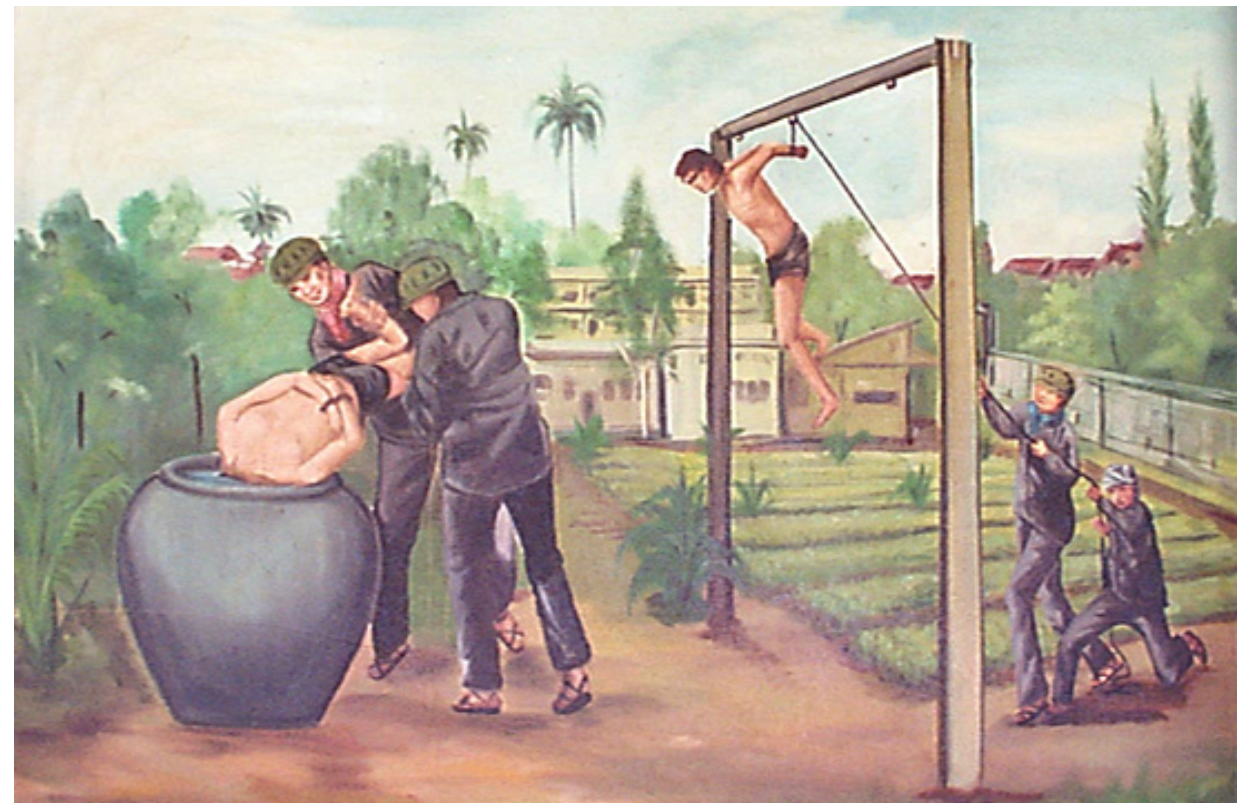

Image 1. Water Torture by Vann Nath. ${ }^{41}$

Especially the upside-down drowning heavily resembles a well-known scene from Buddhist hell, where the damned preet are held headfirst in the same type of water tank. Representations of torments in the subterranean region under control of Yama (or yumreach in Khmer) in bureaucratically exact accordance to the lightness or heaviness of evil deeds committed are well-known and can be found in countless pagodas across country. ${ }^{42}$ Here are two pictures, one showing the upside-down hanging of preet in an old mural at Wat Tway Bongkum (see Image 2) and one showing a modern version of the scenery in the Khmer Rouge stronghold Pailin (see Image 3).

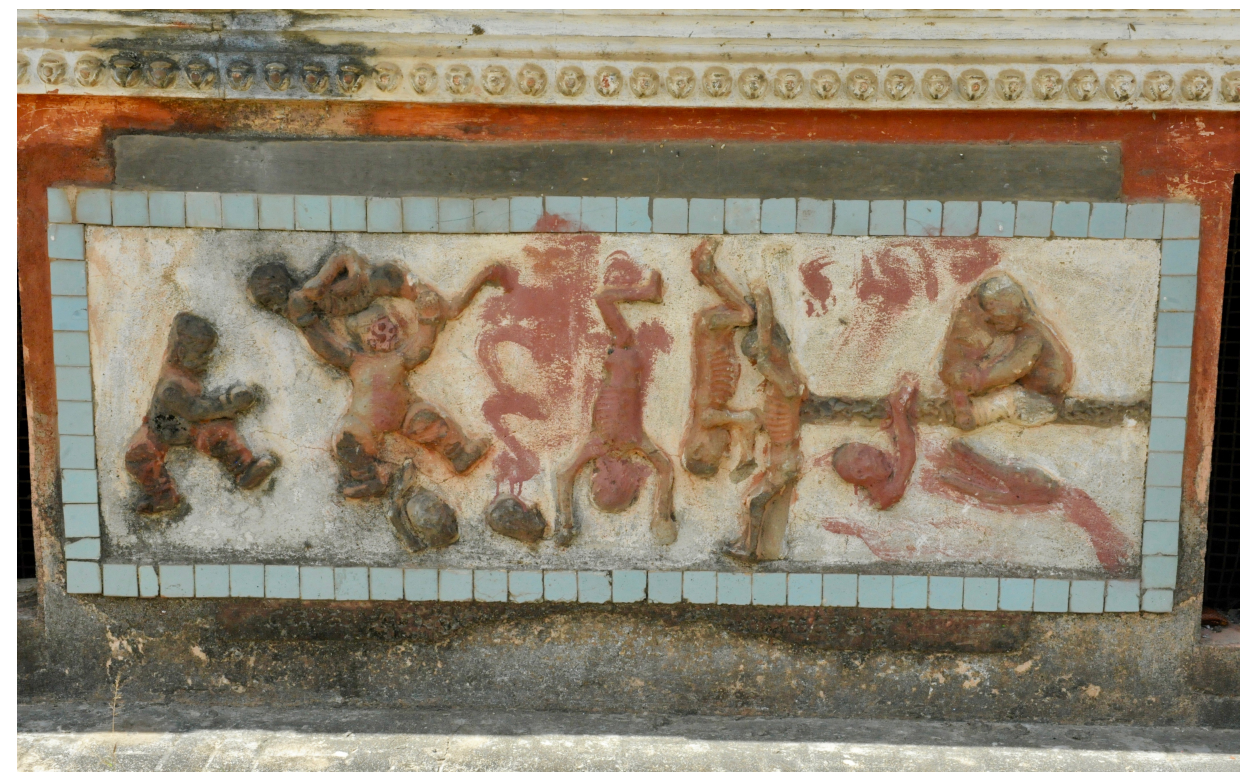

Image 2. Wat Tway Bongkum. ${ }^{43}$

\footnotetext{
${ }^{41}$ Vann Nath, Water Torture, acrylic on canvas, ca. 1980, on display at the Tuol Sleng Genocide Museum and Archive, Phnom Penh.

${ }^{42}$ Harris, Buddhism in a Dark Age, 55.

${ }^{43}$ Wat Tway Bongkum, picture taken by the author, 2017.
} 


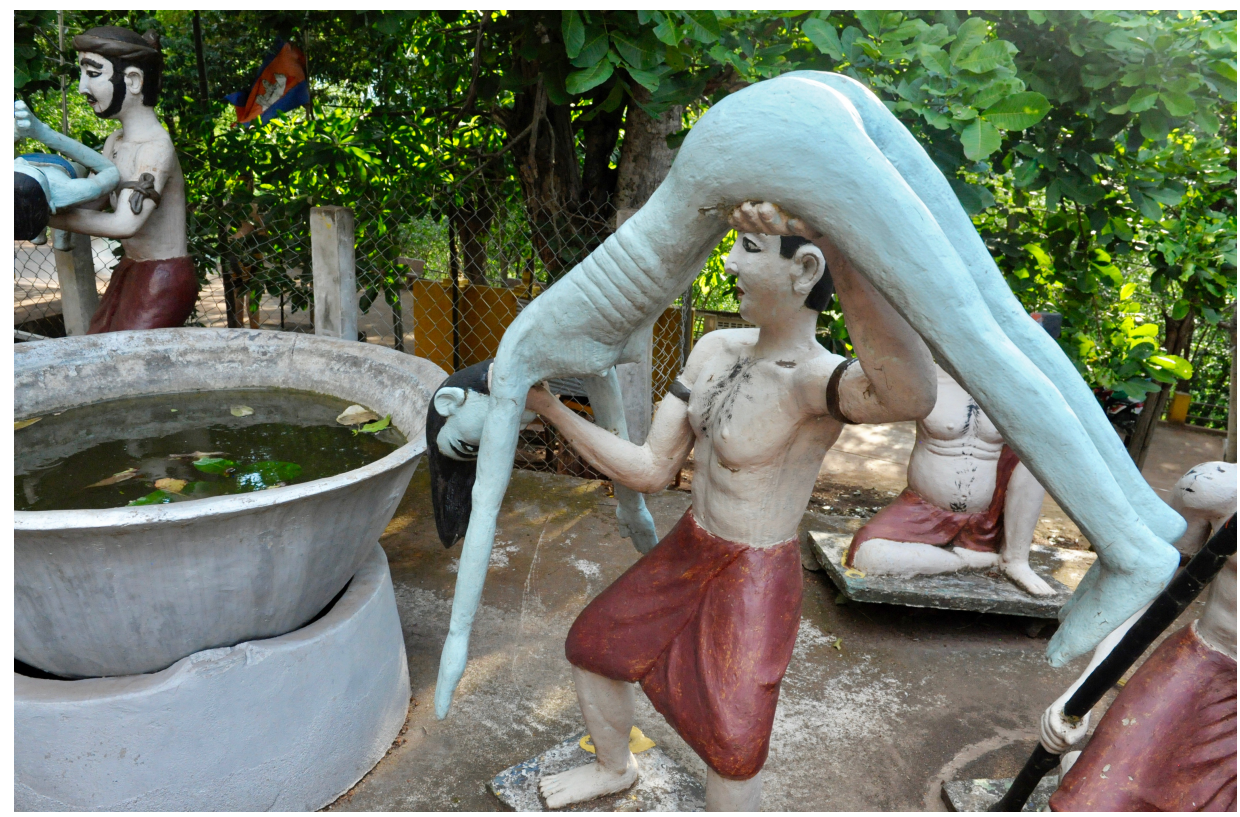

Image 3. Wat Phnom Yat, Pailin. ${ }^{44}$

In a similar vein, the dog to which many inmates had to "pay homage" as a representation of a master-servant relationship also plays a prominent role in Buddhist hell. As scavengers and dung-eaters, dogs are considered especially dirty and belonging to the wilderness and its realms of violence, death and its potency. They were often seen running around cremation sites or in some usually rural areas in spaces where dead bodies had been sacrificed to nature before colonial state administration viewed this practice as unhygienic and "unmodern," gnawing on human remains. ${ }^{45}$ This is also why they-and vultures-became part of the regional Buddhist hell iconography, where they devour the tormented preet (see Image 4).

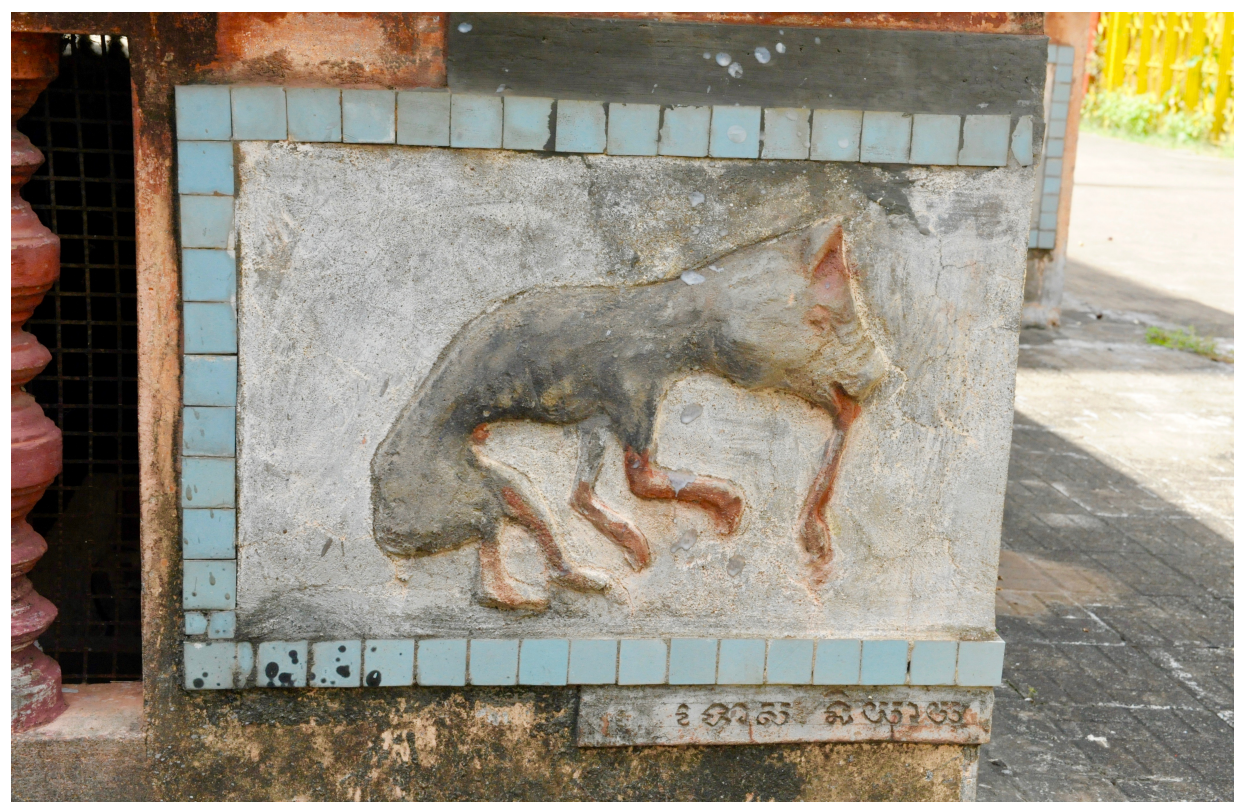

Image 4. Wat Tway Bongkum. ${ }^{46}$

${ }^{44}$ Wat Phnom Yat, Pailin, picture taken by the author, 2015.

45 Compare Jana Igunma, "Meditations on the Foul in Thai Manuscript Art," Journal of the International Association of Buddhist Universities 5 (2015), 69-71.

46 Wat Tway Bongkum, picture taken by author, 2017. 
Paying respect to the dogs as animals of the wild, of out-of-orderness, of violence and death, demonstrates the non-belonging and absolute otherness of the inmates.

\section{Uncovering II: Confessions}

The prime instrument for revealing a traitorous mind was, of course, the confession, which in its final version stood at the end of the interrogation process. It marked the dramatic ritual climax signifying the conversion process into a confessed traitor speaking "truth" to its master. ${ }^{47}$ However, the confession did not only reconstruct a crime; it was also a meandering tool that uncovered a traitorous identity conspiring with foreign powers, first lured into treason at least decades before. For many inmates, a confession went through several drafts, each version with red-inked instructions in the margins by prison chief Duch for the interrogators to ask more about certain individuals and events, or just exclamations that the prisoner was lying-and, in one instance at least, that the prisoner was "too hardheaded," so the interrogator may beat him to death. ${ }^{48}$ Confessions had to be repeated until they corresponded to the regime's master narrative of traitorous Khmer networks conspiring with foreign powers.

Counterrevolutionary behavior was not accidental (at least for those incarcerated in S-21), but confession needed to prove that the inmates had weak and amoral personalities, were part of a larger patrimonial network, and to uncover a sociogram of treason. That way, the confession traced not only the evolution of the alleged crime but also the evolution of becoming one hundred percent Yuon in mind. And it served to uncover not only the fact that the inmate became a foreign agent hiding among the people and within the revolution a long time ago, but also that he or she was part of a larger counterrevolutionary conspiracy. Confessions all started with basic socioeconomic information and ran from early childhood until the day they had been arrested by arrested by Angkar, which translates as "the Organization." It was essential, as stated in a Khmer Rouge manual, to show that they were responsible for economic failures.

In growing rice there are two battles. First, the battle with nature. Second, the battle with destructive enemies. The enemy destruction begins with breaking stalks when seedlings are being transplanted; they don't transplant from the stalk and the roots at all, they break the stalks to destroy, they destroy during the harvest, they destroy during transport, and they destroy in threshing. Raising crops is a technical struggle, a class struggle, a struggle between revolution and no revolution. 49

A large chunk of a confession centered on admitting to economic sabotage or slowing down the work of a cooperative to discredit the revolution. Usually, however, the reason that people became traitors in the first place-decades ago, when they were young-was said to be moral weakness relating to individualistic thinking, a poison of the social milieu they had been part of. Typically, someone else-a close contact, such as a teacher, village chief, or boss at work

\footnotetext{
${ }^{47}$ Michel Foucault, The History of Sexuality, Volume 1: An Introduction, trans. Robert Hurley (New York: Vintage Books, [1976] 1990).

48 Judy Ledgerwood, "The Cambodian Tuol Sleng Museum of Genocidal Crimes: National Narrative," Museum Anthropology 21, no. 1 (1997), 86. In the surviving documents, the upper leadership of S-21 very rarely explicitly allowed "hot methods" to be employed until death, as this went against regulations putting the value of information for the collective first; compare for example, Archived Document, "Letter from Duch to Pon," Document No. E3/376, Virtual Tribunal Archive, Extraordinary Chambers in the Courts of Cambodia (ECCC). Document was archived on April 8, 2019 at the ECCC in Phnom Penh. Killing an inmate before he delivered a complete confession was a punishable crime that could lead to the imprisonment and, consequently, death of the interrogator; Archived Document, "The Activities of Rin in the Office S-21," Document No. D16983, Sterling Library, Yale University and the Documentation Center of Cambodia, Phnom Penh.

${ }^{49}$ Meng-Try Ea, "Defining the Enemies of Angkar," Searching for the Truth 32 (2002), 23, accessed November 2020, http:// d.dccam.org/Projects/Magazines/Previous\%20Englis/Issue32.pdf.
} 
-told them how bad the revolution was; how people were starving; how it ended all material possession, freedom, and religion; and that they would hide and build up forces to bring down the revolution. Counterrevolutionary weakness-making Khmer people receptive to manipulative speeches by imperialist and capitalist others-was usually framed in ways very similar to Buddhist moralities, in which individualistic motives such as greed, delusion, and anger are the root causes of bad behavior. A well-known example for these three individualistic motives as root causes for immoral action is the regionally highly influential Buddhist text on the three realms of the world, Trai Bhüm.50 In a similar vein, non-revolutionary thoughts and behaviors were, in confession, generally said to be caused by individualistic motives such as greed (such as craving private property or luxury consumption or "being excited to meet the family"), 51 power (enjoying authority and control over others), 52 and/or sexual lust (having extramarital affairs, stalking innocent women). ${ }^{53}$ Even interrogators themselves had to be vigilant not to fall prey to individualistic thoughts that placed personal comfort and pleasures above the collective:

Must raise the flag [among our cadres] of eliminating the three types of individualisms:

- Individualism in laziness, lazy in thinking, lazy in reflecting, lazy in interrogating harshly in order to deeply understand the true nature of a problem, all the way to being lazy, lazy to walk, lazy to write, lazy to listen, lazy to speak and instruct, lazy to reeducate. The weakest type of laziness is just thinking of sleep.

- Individualism in viewpoint: That we see only ourselves as all good and correct in all then criteria. Meaning that whatever one thinks is all correct, whatever one does is all good.

- Individualism in power and authority: Not sticking to the concrete, not sticking close to the movement, not sticking close to the masses. And power is the second key factor, that is, must study from the movement, must grasp. .54

The interrogators, guards, medics, and other types of S-21 personnel arrested and tortured into confession themselves were all accused of sabotaging security work due to greed, laziness, sexual cravings, or a will to power over others. All confessions followed a uniform template. They served the purpose of showing that traitors were long-term conspirators and

50 King Lithai, Three Worlds According to King Ruang. A Thai Buddhist Cosmology, ed. and trans. Frank E. Reynolds and Mani B Reynolds (Berkeley: University of California, 1983), 61-65.

51 Archived Document, "Diary of a DK official," Document No. D00417, Sterling Library, Yale University and the Documentation Center of Cambodia, Phnom Penh; Ben Kiernan and Kosal Path, trans., Ieng Sary's Regime: The Diary of the Khmer Rouge Foreign Ministry, 1976-79 (Joint Monograph Translation Series, No. 1, New Haven: The Cambodian Genocide Program, Yale University and the Documentation Center of Cambodia, 1998), 69, accessed September 2018, https:/ / gsp.yale.edu/ieng-sarys-regime-diary-khmer-rouge-foreign-ministry-1976-79.

52 Document, “The Pon-Tuy Notebook," Document No. E3/73, Virtual Tribunal Archive of the Extraordinary Chambers in the Courts of Cambodia (ECCC), 13. The document was accessed and received on April 8, 2019 in Phnom Penh, Cambodia.

${ }^{53}$ See for example, Archived Document, "The Confession of Prisoners Who Involved in Having Sexual Misconduct with Women," Document No. D15417, Sterling Library, Yale University and the Documentation Center of Cambodia, Phnom Penh; Archived Document, "Biography and Treacherous Activity of Neou Kantha, Interrogator of Hot Group," Document No. D17021, Sterling Library, Yale University and the Documentation Center of Cambodia, Phnom Penh.

${ }^{54}$ Document No. E3/ 833, 34. 
that this was a counterrevolutionary activity of great proportions, ongoing for decades. Former Minister of Information $\mathrm{Hu} \mathrm{Nim}$, for instance, declared:

I would like to tell the party, with respect: After Brother No 2 had two work meetings with me, the last day being 10 April 1977, I gave myself to the party. From then on, I have been doing self-criticism every day. I see that my criminal acts against the Organisation, against the Communist Party of Kampuchea, against the nation and people of Kampuchea, are of great dimension. ${ }^{55}$

Being on the other side of morality and conspiring against the people made one thing clear to $\mathrm{Hu} \mathrm{Nim}^{\prime}$ s confession personality: "I'm not a human being, I'm an animal." 56 All confessions ended with a list of traitors that served to reveal networks of enemies (khsae). Inmates provided lists of names of co-conspirators under torture. Some names were real, and others made up. Some tried to list names of people who had been previously arrested. ${ }^{57}$ The Khmer Rouge were not so much interested in reconstructing a crime but rather reconstructing moral flaws as a source of treason. They constructed a complete sociogram of a respondent's life course alongside everyone the inmate ever knew and, of course, all his or her superiors and subordinates through time.58 The list of names was often turned into a representation of a counterrevolutionary network (Image 5).

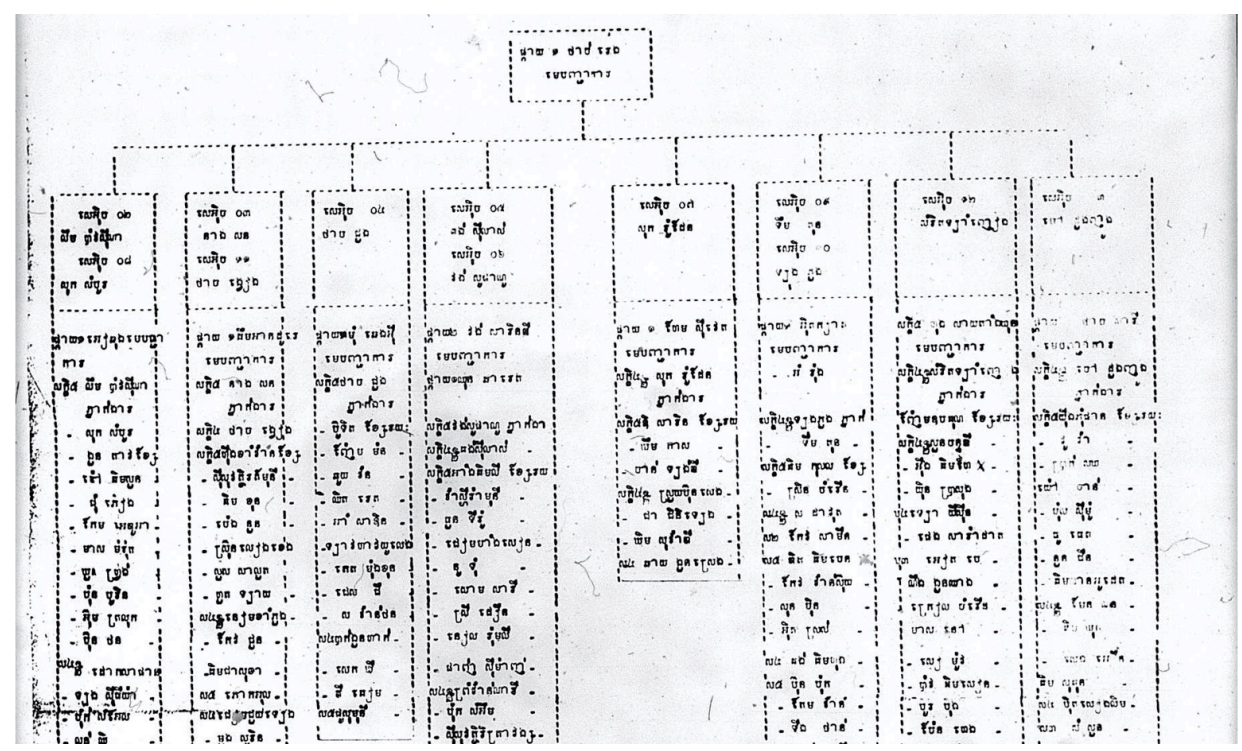

Image 5. Graph of "CIA Networks." 59

55 Anthony Barnett, Ben Kiernan, and Chanthou Boua, “The Bureaucracy of Death: Documents from Inside Pol Pot's Torture Machine," New Statesman, May 2, 1980, 676.

56 Archived Document, "Confession of Hu Nim alias Phoas, Minister of Information, Press and Culture: on the History of C.I.A," Document No. D00067, Sterling Library, Yale University and the Documentation Center of Cambodia, Phnom Penh.

57 The New Zealander Kerry George Hamill, obviously a Beatles fan, amongst others confessed that he went to a course conducted by a "professor Pepper" at the University of Waikato; compare Archived Document, "The confession of Kerry George Hamill," Document No. D07139, Sterling Library, Yale University and the Documentation Center of Cambodia, Phnom Penh.

58 Archived Document, “An interview with the Khmer Rouge Survivor, by David Hawk," Document No. D17198, Sterling Library, Yale University and the Documentation Center of Cambodia, Phnom Penh, 10.

59 Graph of "CIA networks" in a province, drafted by S-21 personnel. Archived Document, "CIA Agents and other Networks in Province," Document No. D07359, Sterling Library, Yale University and the Documentation Center of Cambodia, Phnom Penh. 
These networks had to be uncovered, outlined, and tracked. Likewise, their non-Khmer, animal-like nature belonging to Vietnamese, CIA, or KGB networks had to be shown and outlined in the confessions. This resulted in at times paradoxical end statements such as this one, where a former electrical worker declared his guilt and his deserving of death while also claiming not to have betrayed the revolution:

I am not a member of the CIA. I confessed to being CIA when confronted with my guilt. I beg the Organization to [kill] me because I have not followed the revolution. ... I deserve to die because the Organization had [once] trusted me. I no longer wish to live, make no protests to the Organization, by way of seeking justice. But I must declare that in my heart I have not betrayed the Organization at all. I declare my guilt ... because I am dying. Long live the glorious revolution! Long live the Revolutionary Organization!60

\section{Aggregation in a Mass Grave or Liminality in Death}

Finally, othering, liminality, and semiotics of "Vietnameseness" also surface in the concluding phase of the S-21 liminal ritual, the aggregation stage. For one, the killing of infants by hitting them against a tree "is part of a well-known lexicon of atrocities purportedly committed by the Vietnamese during the early nineteenth century." 61 And of course, throwing dead enemies into a mass grave has the obvious symbolic meaning of signaling death without worth to the collective. However, there is more to the execution process. The classic interpretation of the aggregation phase of rites of passage would be a stage in which initiates re-enter society with a newly attained status and identity. ${ }^{62}$ The death practices at the execution site Choeung Ek are either a case of this re-entering or a case of permanent liminality for "passengers" - ghosts, in this case- that do not transition into rebirth. What is obvious is that mass graves are against Khmer death rituals. But what are Khmer death rituals exactly, and how do the mass graves relate to them?

The first interpretation would view the mass burials as an aggregation into the social status of a Vietnamese. Ethnic Khmer Cambodians strongly prefer cremation over burial, with burial considered a Chinese, Sino-Khmer, and especially Vietnamese practice. Most classic Khmer religious texts on death rituals "ignore burial as an option." 63 During the mid- until the late 20th century at least, burying the dead, therefore, has strong non-Khmer overtones, if not a specifically Vietnamese iconography. Fitting for this hint at a symbolic dimension to the death practices is that the many executed ethnic Vietnamese were not killed at Choeung Ek, as highlighted by Him Huy, who was in charge of transporting victims there.64 Even more strikingly, Westerners were taken to a place near the prison and-against what the upper echelons of the party must have considered "Western" practice-burned on orders from above. 65 This ethnic variation further underlines the symbolic dimension of execution and burial/cremation practices under the Khmer Rouge. ${ }^{66}$

\footnotetext{
60 Chandler, Voices from S-21, 79.

61 Harris, Buddhism in a Dark Age, 56.

62 Turner, The Ritual Process.

63 Erik W. Davis, Deathpower: Buddhism's Ritual Imagination in Cambodia (New York: Columbia University Press, 2016), 50.

64 Archived Document, “Written Record of Witness," May 13, 2008, Document No. E3/935, Virtual Tribunal Archive, Extraordinary Chambers in the Courts of Cambodia (ECCC), Phnom Penh, 3.

65 Christophe Peschoux and Haing Kheng Heng, Itinerary of an Ordinary Torturer: Interview with Duch, Former Khmer Rouge Commander of S-21 (Chiang Mai: Silkworm Books, 2016), 84. See also Alexander Laban Hinton, Man or Monster?: The Trial of a Khmer Rouge Torturer (Durham: Duke University Press, 2016), 165-166.

66 On that note, there is not much known about death rituals under the Khmer Rouge beyond its killing fields for enemies.
} 
Burial is not unknown to ethnic Khmer nor in the religious belief systems of the region, but it usually relates to either "bad deaths" that have no chance of leading to nirvana or to a history before crematories, when corpses had been buried until only bones were left and these remains were later burned. In Khmer traditional beliefs, those who die a tragic and sudden death become ghosts trapped in the world, experiencing grave difficulties in transitioning into an afterworld or rebirth. ${ }^{67}$ Hence, killing Khmer violently and leaving them in a state in between and without later cremation means that-rather than entering a new status as Yuon-it is more likely that liminality (the transition into the afterlife) is halted, and the victims become suffering, trapped ghosts known as khmouch. The fact that Khmer view the ghosts of the killing fields as trapped even today shows the symbolic dimension of a possibly permanent liminal existence that might also inform, knowingly or not, the practices of the Khmer Rouge cadres aimed at punishing the enemy even after his or her death. ${ }^{68}$ For the dead enemies, torments went on. Equally, in classic Buddhist conceptions, though not widely popular in Cambodia, kunapa is the second of four neighboring hells surrounding the eight hot hells: a swamp of rotting corpses. ${ }^{69}$ Like other torture regimes and also like concentration camps, the violent liminal regime of S-21 not only enforces a new status onto the victim through pain, torture and humiliation, it even symbolically captures the victims in liminality in the afterlife, in this case as trapped and suffering ghosts. On a symbolic level at least, the victims are even after death bound to and tortured within the liminal regime of their executioners.

\section{Conclusion: Dead Certainty}

For Arjun Appadurai, ethnic violence involves producing a clear difference from uncertain identities, with its perpetrators aiming to produce a "dead certainty." 70 The lethal rite of passage toward this certainty in the Khmer Rouge central prison S-21 was infused with semiotics of Vietnamese and absolute otherness; of Cold War narratives; of network politics (khsae); of a profound difference in terms of thinking, lifestyle, and biography; of liminal dirt and the loss of markers of humanity; and of Cambodian Buddhist iconography and a discourse of pain, delusion, and transition. This article does not attempt to explain why people killed politically uncertain identities but rather to reveal how violent practices aimed at "manufacturing difference $^{\prime \prime 11}$ followed particular scripts that reflected consecutive stages of a violent rite of passage, expressing cultural ideas of Cold War politics, of "Vietnameseness," and of an imagined Khmer Buddhist moral universe. The enemy had to bow to the CIA, the KGB, and the Yuon head of Ho Chi Minh to demonstrate his misguided political and ethnic allegiances. He had to declare his non-Khmer and traitorous nature within the situation of torture and within his fabricated confession. Within that confession, he had to declare not only his singular act of treason at a given point of time, for which he was imprisoned, but also that he had been and remained part of a larger, long-lasting scheme and that every act of his life was part of a grand local (as well as worldwide) conspiracy. The enemy had to embody an explanation of the economic failures of central planning. He had to signify individualistic lust, greed, and striving for power as the basis of his thinking and acting. And, of course, he had to prove himself polluted and dangerous, a toxin to the purity of the Khmer collective, ${ }^{72}$ thereby justifying his own execution and permanent liminality as a trapped, suffering ghost.

\footnotetext{
${ }^{67}$ John Clifford Holt, "Caring for the Dead Ritually in Cambodia," Southeast Asian Studies 1, no. 1 (April 2012), 6.

68 Caroline Bennett, "To Live Amongst the Dead: An Ethnographic Exploration of Mass Graves in Cambodia," (PhD diss., University of Kent, 2015), 103, https:/ / core.ac.uk/download/pdf/30712406.pdf.

${ }^{69}$ Robert E. Buswell Jr. and Donald S. Lopez Jr., The Princeton Dictionary of Buddhism (Princeton: Princeton University Press, 2014), 455.

70 Appadurai, Dead Certainty.

${ }^{71}$ Hinton, Why Did They Kill?, 225-247.

72 Timothy Williams and Rhiannon Neilson, “'They will Rot the Society, Rot the Party, and Rot the Army'*: Toxification as an Ideology and Motivation for Perpetrating Violence in the Khmer Rouge Genocide?," Terrorism and Political Violence 31, no. 3 (2019), 494-515, accessed November 9, 2020, https:/ / doi.org/10.1080/09546553.2016.1233873.
} 


\section{Bibliography}

Archived Documents. Extraordinary Chambers in the Courts of Cambodia (ECCC), Phnom Penh.

Archived Documents. Sterling Library, Yale University and the Documentation Center of Cambodia, Phnom Penh.

Appadurai, Arjun. "Dead Certainty: Ethnic Violence in the Era of Globalization." Public Culture 10, no. 2 (1998), 225-247.

Barnett, Anthony, Ben Kiernan, and Chanthou Boua. "The Bureaucracy of Death: Documents from Inside Pol Pot's Torture Machine." New Statesman, May 2, 1980, 650-676.

Bennett, Caroline. "To Live Amongst the Dead: An Ethnographic Exploration of Mass Graves in Cambodia." PhD diss., University of Kent, 2015. https://core.ac.uk/download/pdf/ 30712406.pdf.

Buswell Jr., Robert E., and Donald S. Lopez Jr. The Princeton Dictionary of Buddhism. Princeton: Princeton University Press, 2014.

Caswell, Michelle. Archiving the Unspeakable: Silence, Memory, and the Photographic Record in Cambodia. Madison: University of Wisconsin Press, 2014.

Chandler, David. Voices from S-21: Terror and History in Pol Pot's Secret Prison. Berkeley: University of California Press, 2000.

Davis, Erik W. Deathpower: Buddhism's Ritual Imagination in Cambodia. New York: Columbia University Press, 2016.

De Swaan, Abram. The Killing Compartments: The Mentality of Mass Murder. New Haven: Yale University Press, 2015.

Douglas, Mary. Purity and Danger: An Analysis of Concept of Pollution and Taboo. New York: Routledge, [1966] 2002.

Ea, Meng-Try. The Chain of Terror: The Khmer Rouge Southwest Zone Security System. Phnom Penh: Documentation Center of Cambodia, 2005.

" "Defining the Enemies of Angkar." Searching for the Truth 32 (2002), 23-27. Accessed November 9, 2020. http://d.dccam.org/Projects/Magazines/Previous\%20Englis/ Issue32.pdf.

Foucault, Michel. The History of Sexuality, Volume 1: An Introduction. Translated by Robert Hurly. New York: Vintage Books, [1976] 1990.

Harris, Ian. Buddhism in a Dark Age: Cambodian Monks under Pol Pot. Honolulu: Hawaii University Press, 2013.

Hawk, David. “Tuol Sleng Extermination Centre." Index on Censorship 1 (January 1986), 25-32.

Hinton, Alexander Laban. Man or Monster? The Trial of a Khmer Rouge Torturer. Durham: Duke University Press, 2016.

Why Did They Kill? Cambodia in the Shadow of Genocide. Berkeley: University of California Press, 2005.

Holt, John Clifford. "Caring for the Dead Ritually in Cambodia." Southeast Asian Studies 1, no. 1 (April 2012), 3-75.

Huy, Vannak. Bou Meng: A Survivor from the Khmer Rouge Prison S-21, Justice for the Future Not Just for the Victims. Phnom Penh: Documentation Center of Cambodia, 2010.

Igunma, Jana. "Meditations on the Foul in Thai Manuscript Art." Journal of the International Association of Buddhist Universities 5 (2015), 65-82.

Kiernan, Ben and Kosal Path, trans. Ieng Sary's Regime. The Diary of the Khmer Rouge Foreign Ministry, 1976-79. Joint Monograph Translation Series, No. 1, New Haven: The Cambodian Genocide Program, Yale University and the Documentation Center of Cambodia, 1998. Accessed September 2018. https://gsp.yale.edu/ieng-sarys-regimediary-khmer-rouge-foreign-ministry-1976-79.

Ledgerwood, Judy. "The Cambodian Tuol Sleng Museum of Genocidal Crimes: National Narrative." Museum Anthropology 21, no. 1 (1997), 82-98. 
Lithai, King. Three Worlds According to King Ruang: A Thai Buddhist Cosmology, edited and translated by Frank E. Reynolds and Mani B Reynolds. Berkeley: University of California, 1983.

Locard, Henri. Pol Pot's Little Red Book: The Sayings of Angkar. Chiang Mai: Silkworm Books, 2004.

Ly, Sophal. "Social Classes in Democratic Kampuchea." Searching for the Truth 34 (2002), 14-17.

Oberdiek, Ulrich. "Initiation, Selbst-Folter und Folter: Begriffe und Ansätze in der Ethnologie. "In Das Quälen des Körpers: Eine historische Anthropologie der Folter, edited by Peter Burschel, Götz Distelrath and Sven Lembke, 67-98. Köln: Böhlau Verlag, 2000.

Path, Kosal and Angeliki Kanavou. "Converts, not Ideologues?: The Khmer Rouge Practice of Thought Reform in Cambodia, 1975-1978." Journal of Political Ideologies 20, no. 3 (2015), 304-332.

Peschoux, Christophe, and Haing Kheng Heng. Itinerary of an Ordinary Torturer: Interview with Duch, Former Khmer Rouge Commander of S-21. Chiang Mai: Silkworm Books, 2016.

Porée, Anne-Laure. “Tuol Sleng, L’Histoire Inachevée d'un Musée Mémoire." Moussons 30, no. 2 (2017), 151-181.

Turner, Victor. The Forest of Symbols: Aspects of Ndembu Ritual. Ithaca: Cornell University Press, 1967. The Ritual Process: Strucutre and Anti-Strucutre. London: Routledge, [1969] 2017.

van Gennep, Arnold. The Rites of Passage. Chicago: University of Chicago Press, 1960.

Vann Nath. Water Torture, acrylic on canvas, ca. 1980, on display at the Tuol Sleng Genocide Museum and Archive, Phnom Penh.

Vann Nath. A Cambodian Prison Portrait. One Year in the Khmer Rouge's S-21. Bangkok: White Lotus Press, 1998.

Williams, Timothy, and Rhiannon Neilson. "'They Will Rot the Society, Rot the Party, and Rot the Army'*: Toxification as an Ideology and Motivation for Perpetrating Violence in the Khmer Rouge Genocide?." Terrorism and Political Violence 31, no. 3 (2019), 494-515. Accessed November 9, 2020. https:// doi.org/10.1080/09546553.2016.1233873.

Zirfas, Jörg. "Rituale der Grausamkeit, performative Praktiken der Folter." In Die Kultur des Rituals: Inszenierungen, Praktiken, Symbole, edited by Christoph Wulf and Jörg Zirfas, 129-146. München: Fink, 2004. 